CORRIGENDA

Global decrease of serotonin-1A receptor binding after electroconvulsive therapy in major depression measured by PET

R Lanzenberger, P Baldinger, A Hahn, J Ungersboeck, M Mitterhauser, D Winkler, Z Micskei, P Stein, G Karanikas, W Wadsak, S Kasper and R Frey

Molecular Psychiatry (2013) 18, 1146; doi:10.1038/mp.2013.6; published online 29 January 2013

Correction to: Molecular Psychiatry (2013) 18, 93-100; doi:10.1038/mp.2012.93

After publication, it was brought to the authors' attention that a reference had been omitted from the reference list. In the sixth line of the left-hand column on page 94 , it was cited incorrectly as ref. 20. Instead, the citation should have directed the reader to the following reference.
Takano H, Motohashi N, Uema T, Ogawa K, Ohnishi T, Nishikawa M, et al. Changes in regional cerebral blood flow during acute electroconvulsive therapy in patients with depression: positron emission tomographic study. Br J Psychiatry 2007; 190: 63-68.

\title{
The genome-wide supported microRNA-137 variant predicts phenotypic heterogeneity within schizophrenia
}

TA Lett, MM Chakravarty, D Felsky, EJ Brandl, AK Tiwari, VF Gonçalves, TK Rajji, ZJ Daskalakis, HY Meltzer, JA Lieberman, JP Lerch, BH Mulsant, JL Kennedy and AN Voineskos

Molecular Psychiatry (2013) 18, 1146; doi:10.1038/mp.2013.39; published online 26 March 2013

Correction to: Molecular Psychiatry advance online publication, 5 March 2013; doi:10.1038/mp.2013.17
The second author's name was shown incorrectly as MM Chakavarty. The correct name is MM Chakravarty. 